\title{
ACADEMIC INTEGRITY IN HIGHER EDUCATION: IS COLLEGIATE AVIATION EDUCATION AT RISK?
}

\author{
Jeffrey A. Johnson \\ Bowling Green State University
}

\begin{abstract}
Academic integrity needs to be an integral part of collegiate aviation education if students expect to effectively compete in this highly competitive field. Academic integrity is a serious problem in most US colleges and universities today and student dishonesty (in the form of cheating) has presently risen as a major contender for instructors' attention. Recent studies have revealed $40 \%$ to $90 \%$ of all US college students cheat. To presuppose that academic integrity issues are of little importance and do not present serious problems to collegiate aviation could, in time, irrevocably compromise its very foundation. This paper discusses academic integrity and legal issues in higher education, with implications for collegiate aviation.
\end{abstract}

\section{Introduction}

Collegiate aviation faculty, administrators, and students are not exempt in the ongoing battle of maintaining academic integrity in the realm of US higher education. Academic dishonesty has been a well documented problem at colleges and universities (Barnett \& Dalton, 1981; Hale, 1987; Stevens \& Stevens, 1987) that seems to be worsening. The term, academic dishonesty, has been defined by Gehring and Pavela (1994) as:

an intentional act of fraud, in which a student seeks to claim credit for the work or efforts of another without authorization, or uses unauthorized materials or fabricated information in any academic exercise. [Academic dishonesty] also includes forgery of academic documents, intentionally impeding or damaging the academic work of others, or assisting other students in acts of dishonesty. (pp. 5-6)

Gehring and Pavela (1994) have categorized academic dishonesty into four distinct areas:

Cheating: Intentionally using or attempting to use unauthorized materials, information, or study aids in any academic exercise.

Fabrication: Intentional and unauthorized falsification or invention of any information or citation in an academic exercise.

Facilitating academic dishonesty: Intentionally or knowingly helping or attempting to help another to commit an act of academic dishonesty.

Plagiarism: Intentionally or knowingly representing the words of another as one's own in any academic exercise. (pp. 12-13) 
Although collegiate aviation is still a relatively young discipline, academic integrity issues are presenting formidable challenges that have plagued traditional fields of study for quite some time. Research conducted by the Carnegie Council (1979), Levine (1980), and Pavela (1981) indicate that present-day college students value achievement and the ability to compete successfully versus independent scholarship. Most programs in the aviation sciences(e.g., flight and maintenance technologies, aviation management and administration) are highly competitive by nature and the environment alone may be enough to entice some students to cheat. (e.g., flight and maintenance technologies, aviation management and administration) are highly competitive by nature and the environment alone may be enough to entice some students to cheat.

Perhaps what is most disturbing of all, cheating is also prevalent in academic and professional disciplines that could adversely affect the quality of human life. For example, in a research study involving two medical schools, Sirles, Hendrickx, and Circle (1980) found that $87.6 \%$ of sampled premedical students and $58.2 \%$ of medical students reported cheating. Like premedical and medical programs, collegiate aviation has much to lose if academic integrity issues are not taken seriously. According to Benton (1995), "the safety of the aviation industry depends on the ethical and professional conduct of the people involved in the industry, yet the topic of ethics is strangely absent in the curricula of many university aviation programs" (p. 22). Curricula is already strained in the aviation field and is not readily receptive to incorporating additional courses such as ethics (Benton, 1995).

\section{Higher Education: A Crisis in Values}

As American colleges and universities approach the Twenty-First Century, an underlying factor eroding academic integrity is a crisis in values. A recent study completed by 16 representatives from education, business, and nonprofit organizations known as the Wingspread Group on Higher Education (1993) revealed some very disturbing trends in higher education:

The nation's colleges and universities are enmeshed in, and in some ways contributing to, society's larger crisis of values. Intolerance on campus is on the rise; half of big-time college sports programs have been caught cheating in the last decade; reports of ethical lapses by administrators, faculty members and trustees, and of cheating and plagiarism by students are given wide-spread credence .... The weakening of the role of family and religious institutions in the lives of young people, the increase in the number of people seeking the benefits of higher education, and what appears to be the larger erosion of core values in our society make this traditional role all the more important. (p. 4)

A crisis in values in American higher education can be partially attributed to changes in student values. Gehring and Pavela (1994) found that students engage in academic dishonesty because "the ability to succeed at all costs is one of the most cherished values. Students are more interested in financial security, power, and status and less committed to altruism, social concerns, and learning for the sake of leaming" (p. 9). 


\section{Perceptions of Academic Dishonesty}

Students cheat for a variety of reasons and sometimes engage in acts of academic dishonesty without even realizing it. Gehring and Pavela (1994) noted in their research that a frequently cited reason students engage in cheating is a lack of awareness of how academic dishonesty is defined and what constitutes academic dishonesty. This notion is exemplified by research study results (see Table 1) of the perceptions of students and faculty concerning discrepancies in perceptions of cheating (Graham, Monday, O'Brien, \& Steffen, 1994).

\section{Table 1}

Percent of Students and Faculty who View Behavior as Cheating and Percent of Students who Report Having Engaged in Each Behavior

\begin{tabular}{|c|c|c|c|}
\hline Behavior & $\begin{array}{l}\text { Percent of students } \\
\text { view cheating }\end{array}$ & $\begin{array}{l}\text { Percent of faculty } \\
\text { view cheating* }\end{array}$ & $\begin{array}{l}\text { Percent of students } \\
\text { have done behavior }\end{array}$ \\
\hline Looking at notes during a test & 99.6 & 100.0 & 25.8 \\
\hline $\begin{array}{l}\text { Arranging to give or } \\
\text { receive answers by signal }\end{array}$ & 98.9 & 100.0 & 4.5 \\
\hline Copying during an exam & 98.9 & 100.0 & 26.0 \\
\hline Taking a test for someone else & 93.5 & 100.0 & 2.7 \\
\hline Asking for an answer during an exam & 98.2 & 100.0 & 26.0 \\
\hline Giving answers during an exam & 97.9 & 100.0 & 20.6 \\
\hline Copying someoneelse's term paper & 97.2 & 100.0 & 13.7 \\
\hline Allowing a student to copy on a test & 96.0 & 100.0 & 23.5 \\
\hline $\begin{array}{l}\text { Having someone write } \\
\text { a term paper for you }\end{array}$ & 95.9 & 100.0 & 97.9 \\
\hline $\begin{array}{l}\text { Finding a copy of an exam and } \\
\text { memorizing the answers }\end{array}$ & 95.1 & 100.0 & 17.1 \\
\hline Writing a paper for someone else & 93.6 & 100.0 & 9.5 \\
\hline $\begin{array}{l}\text { Giving test questions to a student } \\
\text { in a later session }\end{array}$ & 86.9 & 97.9 & 49.6 \\
\hline $\begin{array}{l}\text { Not contributing a fair share in a } \\
\text { group project }\end{array}$ & 79.4 & 79.6 & 36.4 \\
\hline Allowing someone to copy homework & 74.6 & 83.0 & 63.1 \\
\hline $\begin{array}{l}\text { Using an old test to study without } \\
\text { the teacher's knowledge }\end{array}$ & 66.0 & 83.3 & 37.5 \\
\hline Using a paper for more than one class & 45.9 & 77.1 & 53.6 \\
\hline
\end{tabular}

Note. "Percent who responded that the behavior was not very severe, severe, or very severe form of cheating. From "Cheating at Small Colleges: An examination of Student and Faculty Attitudes and Behaviors," by M. Graham, J. Monday, K. O'Brien, and S. Steffen, 1994, Joumal of College Student Development, 35, p. 256. 
This research study also revealed that faculty and students agree on the top three reasons why a student would cheat. The reasons faculty and students report that students cheat is that: (a) they need a better grade (students $72.5 \%$ and faculty $84.5 \%$ ), (b) they did not have time to study (students $60.4 \%$ and faculty 69.9\%), and (c) they saw an opportunity and just took it (students $33.5 \%$ and faculty 61.5\%) (Graham, Monday, O'Brien, \& Steffen, 1994).

\section{Legal Implications of Academic Integrity}

In a highly litigious society, cases of academic dishonesty occasionally end in the courts although the practice is not highly prevalent. According to Gehring and Pavela (1994), faculty are often reluctant to report alleged acts of academic dishonesty because they fear an impending lawsuit. This reaction "stems from the unfounded belief that if they report an alleged act of academic dishonesty, the student will be exonerated since it is only the faculty member's word against the student's and having been exonerated, the student will then bring suit for defamation" (p. 16). In this scenario, faculty and administrators are protected by their "qualified immunity/privilege" status (Vargo v. Hunt, 1990).

In addition to faculty reluctance, the courts do not typically view alleged cases of academic dishonesty as "desirable" cases. According to Kaplin and Lee (1995), the courts are generally reluctant to get involved in academic disputes involving matters of course content, teaching methods, grading, or classroom behavior. The courts view these responsibilities as belonging to educators and administrators. Cases involving academic dishonesty at colleges and universities are academic matters. The courts have found that faculty and administrators must comply with the hearing panel's findings and decisions made in academic dishonesty cases on the campus. In Lightsey v. King (1983), a midshipman from the U.S. Merchant Marine Academy brought action for declaratory and injunctive relieve against the Academy for its refusal to change the grade of "zero" after the midshipman was exonerated of cheating by the academy's honor board. As a result, the court found that by holding the honor board hearing and then disregarding its result, the Academy had violated the midshipman's right to due process.

If an alleged case of academic dishonesty is tried in court, faculty members are afforded some protection. In Hall v. Medical College of Ohio (1984), a former medical student who was dismissed from school because of alleged academic dishonesty appealed from summary judgment entered by the United States District Court in favor of the Medical College of Ohio. After reviewing the case, the Sixth Circuit US Court of Appeals affirmed the decision of the lower court and held that: (1) the medical school was an arm of the state and thus immune from suit brought by the discharged student; (2) school officials were entitled to immunity from liability for damages in their individual capacities; and (3) since the school had good cause for expelling the student, his expulsion was not caused by a due process violation that may have occurred when he was denied assistance of legal counsel at his disciplinary hearing.

In Jaska $v$. Regents (1984), a university student who was suspended for one term for cheating on a final examination brought suit against the president, dean, and regents of the university alleging that he was denied procedural due process. The student argued that he was not allowed representation at the hearing, was not given a transcript, could not confront the student who reported the cheating, and did not receive a detailed statement against him. The court found that the student had a liberty and a property interest in continuing his education at the university, although the court rejected the student's claim that his due process was violated. The court ruled in favor of the regents and found that, although the student was entitled to procedural due process, the fact that some procedures specified in the university's disciplinary manual were not followed did not deny the student due process. 
In both cases (Hall v. Medical College of Ohio, 1984 \& Jaska v. Regents, 1984) similarities exist in respect to students accused of cheating. The courts have said that students accused of violations of academic integrity are entitled to the higher level of due process procedural protection guaranteed in school disciplinary proceedings rather than the level of protection afforded in academic matters (Constitutional Law 278.5(7), cited in Jaska v. Regents, 1984). A school's disciplinary proceeding is not a criminal trial, and a student accused of cheating is not entitled to all the procedural safeguards afforded criminal defendants (Colleges and Universities 9.35(4), cited in Jaska $v$. Regents, 1984).

\section{Faculty Perspectives in Addressing Academic Dishonesty}

Collegiate aviation faculty, like those in other fields of study in higher education, need to be consciously aware and actively involved in reducing academic dishonesty. Historically, institutions of higher education have handled academic dishonesty from a moral perspective by using and enforcing honor codes (Kibler, 1994), although many of these institutions have replaced honor codes with administrative disciplinary systems (Hardy, 1982; Kibler, Nuss, Paterson, \& Pavela, 1988). Gehring, Nuss, \& Pavela, 1986; Georgia, 1989; Pavela, 1981, Rutherford \& Olswang, 1981; and Kibler et al. (1988) proposed that academic dishonesty prevention must begin at the institutional level. Research from Geist, Fagan, Hardy, Singhal and Johnson (as cited in Gehring \& Pavela, 1994) provides effective strategies for faculties to combat academic dishonesty:

- Develop course objectives and tie all tests and assignments to those objectives. Unrealistic, trite, or irrelevant assignments provide students with a rationale to be dishonest.

- Faculty members should know their students and their capabilities. Frequent written assignments and testing will provide an opportunity to learn the kind of work students are capable of performing. Students who know that faculty members are aware of their abilities are less inclined to substitute the work of others as their own. Courses in which there is only one examination or paper put excessive pressure on students to perform. This type of "all or nothing" environment breeds academic dishonesty.

- Faculty members should use part of the first class session to review university standards and let students know why academic integrity is important. Members of a student honor council, or academic integrity advisory committee, could also be invited to make a brief presentation.

- The course syllabus should contain a statement alerting students to the institution's academic integrity policies and affirming the teacher's intention to abide by them.

- A pool of test questions should be developed that would permit changing tests each term.

- Teachers should supply official examination booklets at examinations.

- "Take home" examinations or lab assignments should be avoided, unless student collaboration is desired.

- The use of standard examinations contained in teachers' manuals should be avoided, since 
resourceful students are often able to obtain such publications.

- Students should be informed that they will not need anything for the test except a pen or pencil. All other materials must be left outside of class or at the front of the room.

- Students in large classes should be required to show proper identification before taking examinations.

- Students should be expected to write their names on examination booklets in ink.

- Both questions and answers on short-answer examinations should be scrambled, especially in large classes.

- Students might be seated randomly in examinations, but exam booklets should be numbered and gathered by row, so seat location can be determined. It is especially important to prevent groups of students from entering the room together and sitting near each other.

- Examinations must be carefully and diligently proctored by an adequate number of proctors, unless an effective "honor code" has been adopted.

- Faculty members should consider allowing students to make handwritten notes on a 3" x 5" card for use during examinations. This procedure helps students organize what they have leamed, and reduces the temptation to rely on "crib" sheets.

- Graduate assistants or student graders must not be given a solutions manual for the entire course.

- Students might be informed before the examination that significant numbers of completed examinations are photocopied before being returned. Such a practice may discourage students from altering retumed examinations and submitting them for regrading.

- Students assigned to write substantial papers might be asked to give a relevant oral presentation to the class and respond to questions from the teacher and other students. Such a practice has the educational value of giving students some additional experience in speaking before a group. Also, students assigned to write substantial papers might be required to meet at least once with the instructor to review the topic and discuss the ongoing research which the student has undertaken.

- Instructors might require that an outline and a first draft be included when students submit major papers. (pp. 13-16)

Additional strategies for collegiate aviation educators (see Table 2) include the reliance on oral examinations during aviation related activities. If properly administered, oral examinations not only have the advantage of reducing or eliminating academic dishonesty, but can challenge students' ability to apply what they have learned (a disadvantage of passive, lecture-style environments). For example, flight students enrolled in upper level courses (e.g., turbine aircraft systems and operations) could be tested in a predetermined simulation exercise involving their psychomotor and oratory skills. At appropriate times throughout the simulation, the instructor could ask questions and have the student explain the material. In aviation administration 
courses, instructors could set aside individual time with each student, give the student a one page written case study on improving airport security at a given airport and ask the student questions, give explanations, and defend their rationale during the oral examination. It would not take a faculty member a great deal of time to determine if the student has a thorough understanding of the material, by assessing each student's responses.

Table 2

Strategies for Collegiate Aviation Faculty Members in Reducing Academic Dishonesty and Improving Instructional Effectiveness

\section{INSTRUCTIONAL STRATEGIES}

1. Oral examinations

2. Intructor/student simulations

3. Encourage student collaboration during out of class "real world" projects

4. Sign an academic integrity agreement form and learning contract with students

5. For student co-ops, require a journal of the student's daily/weekly activities unique to the activity site while monitoring the student's performance through the co-op supervisor

Although most faculty consider student collaboration outside of class as cheating, this mind set is antagonistic to the principles that employers espouse to their employees. Encouraging student collaboration in meaningful, "real world" projects prepares students for the realities of the aviation/aerospace industry after graduation. In a global society where the emphasis is placed on teamwork and team-oriented tasks, out of class student collaboration can be effectively utilized to achieve those ends while individualistic assignments can be handled in-class or by other means.

Another method of reducing academic dishonesty is to sign an academic integrity agreement and a learning contract with each student. During the first class meeting, the instructor needs to explain the policies outlined by the institution for cheating and other forms of academic dishonesty in addition to outlining the penalties for such actions (Singhal \& Johnson, 1983). A learning contract specifically outlines the leaming objectives as agreed upon by the student and the instructor for the course. Both of these "contracts" will enhance communication effectiveness between both parties.

For students involved in cooprerative education (co-op), requiring the student to keep a daily/weekly log of the experiences while maintaining regular and effective communication with the co-op supervisor can provide a means of reducing academic dishonesty. By maintaining a communication outlet between instructor and the co-op supervisor, the instructor can verify actual experiences with entries in the student $\log$ under the direction and leadership of the co-op supervisor. 


\section{Conclusions}

Academic dishonesty is a serious problem in American colleges and universities, and seems to be getting worse. Prevalent acts of cheating have affected the professional fields such as medicine (Sirles, Hendrickx, and Circle, 1980). This seems to draw suspicion that if undergraduates cheat, they will continue to cheat in medical school and in the professional world as physicians. In collegiate aviation, strong ethical and professional conduct affects the safety of the aviation industry at large (Benton, 1995) and, like the medical field, condoning cases of academic dishonesty in the classroom may very well lead to cheating and other "short cuts" in the professional world.

Cheating in the professional world of aviation may lead to loss of life. Consider the aviation student who may cheat when it comes to departing when the weather is marginal as a student pilot, the airport administration student who cheats in a class project when designing a secure, weapon-free "sterile area," and the aviation maintenance technology student who cheats on performing acceptable aircraft repair methods. Can collegiate aviation educators make an assumption that dishonest behavior will cease once these students enter their respective professions in the aviation industry as the next generation of airline/corporate pilots, airport administrators, and aircraft maintenance technicians?

Collegiate aviation educators must become active participants in the effort against academic dishonesty in higher education if students are expected to perform at their best in school and in the labor force. To actively instill strong ethical and moral values in the classroom is paramount. The finest collegiate aviation programs will fall short of meeting high expectations of its graduates because ". . the best educational experience should be taught in the context of values. The acknowledgment of our values with respect to ethics, family, religion, and society is a key point and should be a framework for our daily life" (Lehrer, 1995, p. 6). The decisions that collegiate aviation educators make, or fail to make, regarding academic integrity have widespread and long-lasting repercussions not only on their students, but on the people they serve as well.

\section{References}

Barnett, D. C., \& Dalton, J. C. (1981). Why college students cheat. Joumal of College Student Personnel, 22 , 545-551.

Benton, P. (1985). Ethics in aviation. Journal of Aviation/Aerospace Education and Research, 5(2), 22-25.

Bunyan, J. (1980, November). Symposium on cheating. Today's Education, 30-42.

Carnegie Council on Policy Studies in Higher Education. (1979). Fair practices in higher education: Rights and responsibilities in a period of intensified competition for enrollment. San Francisco: Jossey-Bass.

Gehring, D. D., Nuss, E. M., \& Pavela, G. (1986). Issues and perspectives on academic integrity. Columbus, $\mathrm{OH}$ : National Association for Student Personnel Administrators.

Gehring, D. D., \& Pavela, G. ( 1994). Issues and perspectives on academic integrity (2nd ed.). Washington, DC: National Association of Student Personnel Administrators. (2nd ed.). Washington, D.C.: National Association of Student Personnel Administrators.

Georgia, R. T. (1989). Permissiveness and discipline in the higher education setting: A prolegomenon. NASA Journal, 27(2), 90-94.

Graham, M., Monday, J., O'Brien, K., \& Steffen, S. (1994). Cheating at small colleges: An examination of student and faculty attitudes and behaviors. Journal of College Student Development, 35, 255-260.

Hale, J. L. (1987). Plagiarism in classsroom settings. Communication Research Reports, 42, 66-70.

Hall v. Medical College of Ohio, 742 F. 2d 299 (6th Cir. 1984). 
Hardy, R. J. (1982). Preventing academic dishonesty: Some important tips for political science professors. Teaching Political Science, 9(2), 68-77.

Jaska v. Regents, 597 F. Supp. 1245 (E D. Mich. 1984)

Kaplin, W. A., \& Lee, B. (1995). The law of higher education (3rd ed.). San Francisco: Jossey-Bass.

Kibler, W. L. (1994). Addressing academic dishonesty: What are institutions of higher education doing and not doing? NASPA Journal, 31 (2), 92-101.

Kibler, W. L., Nuss, E. M., Paterson, B. G., \& Pavela, G. (1988). Academic integrity and student development: Legal issues, policy perspectives. Asheville, NC: College Administration Publications.

Lehrer, H. R. (1995). What should be included in a complete aviation education? Journal of Aviation/ Aerospace Education and Research, 5(2), 5-6.

Levine, A. (1980). What dreams and heroes died: A portrait of today's college student. San Francisco: Jossey-Bass.

Lightsey v. King, 567 F. Supp. 645 (E.D.N.Y. 1993).

Pavela, G. (1981, February 9). Cheating on campus: Who's really to blame? Chronicle of Higher Education, 64.

Rutherford, D. G., \& Olswang, S. G. (1981). Academic misconduct: The due process rights of students. NASPA Joumal, 19(2), 12-16.

Sierles, F., Hendrickx, I., \& Circle, S. (1980). Cheating in medical school. Journal of Medical Education, 55, 124-125.

Singhal, A. C., \& Johnson, P. (1983). How to halt student dishonesty. College Student Journal, 17, 13-19.

Stevens, G. E., \& Stevens, F. W. (1987). Ethical inclinations of tomorrow's managers revisited: How and why students cheat. Journal of Education for Business, 63(1), 24-29.

Vargo v. Hunt, 581 A 2d 625 (Pa. Super. 1990).

Wingspread Group of Higher Education. (1993). An American imperative: Higher expectations for higher education, Washington, D.C.: The Johnson Foundation, Inc. 